\title{
Impact of Parent Brand on Brand Extension: A case of FMCG Brands in Pakistan
}

\author{
Zafarullah Chandio \\ Institute of Business \& Technology, Karachi \\ Sarah Zafar \\ Institute of Business \& Technology, Karachi
}

\begin{abstract}
Purpose: The aim of this research is to find out the impact of existing brand on extension by using three different parent brand and their extensions of FMCG industry. This study will investigate that what are some of the factors of the parent brand which can play a role of driver for the brand extension.

Methodology/Sampling: Primary data was collected from respondents at various locations of Karachi. Questionnaire was administered in 100 randomly selected samples; sampling frame was respondents \& students from different locations of Karachi. Already established scales were used for measuring selected variables. Data was analyzed through correlation \& regression.

Findings: Results explains that awareness, loyalty, image and quality are positively significant in the case of lifebuoy brand whereas personality has the negative significant impact for the customer evaluation of brand extension. It showed that if the product is aligned with the consumer personality.

Practical Implications: This research is useful for the marketing sales managers of the organizations in aligning their products with the personality of consumers.
\end{abstract}

Keywords: Foreign direct investment; economic growth, Pakistan.

JEL Classification: M300, M390

\footnotetext{
* The material presented by the authors does not necessarily portray the viewpoint of the editors and the management of the Institute of Business \& Technology (IBT).

* Zafarullah Chandio: zafar.chandio@ibt.edu.pk

* Sarah Chandio: sarah.chandio@ibt.edu.pk

CJMSS is published by the Institute of Business and Technology (IBT). Main Ibrahim Hydri Road, Korangi Creek, Karachi-75190, Pakistan.
} 


\section{INTRODUCTION}

Pakistan has become an eye catching for the international investors and large MNC's due to the large growth in FMCG market few decades ago. Many of the national and international organization make their product a highly reputed brand which is might be their master brand, parent brand or corporate brand, after that making the brand successful if the organization wants to enter in to new product category the brand extension has become the trend in the market whether it's a national or an international market(Aaker and Keller, 1990) This is because to minimize the risk from the existing brand if the extended brand not get success (Martinez and Pina, 2003).

Although the name of the brand doesn't comes any of the financial books of the company but it has worth more than any other assets (Badenhausen 1996). That means brand extension is the strategy to minimize the risk of damage to the original existing brand name that will become Parent brand after having brand extension.

After having the brand extension strategy how parent brand plays a role to drive it and make the extension successful, this study will investigate that what are some of the factors of the parent brand which can play a role of driver for the brand extension. The significance of this study is for the organizations, means when to launch their extensions and what are factors of Existing brand which can play the role of driver brand for the extension.

\subsection{Statement of Problem}

After launching the brand extension the previous brand which was existing becomes a parent brand, by the strategy of brand extension enables the company to have the opportunity to enter into the new product category, so it is important to know that what parent brand is doing for the acceptability of the extension in market. Whether consumer purchases brand extension due to the knowledge, quality and other variables of parent brand or brand extension itself make an image in front of the consumers.

\subsection{Objectives of research study}

To find out the impact of existing brand on extension by using three different parent brand and their extensions of FMCG industry.

\subsection{Purpose of the study}

The study and its purpose is to know that what are those factors of parent brand which makes the brand extension a successful brand or a worst brand which will become known to us through the acceptability of the brand extension by the consumers Since the ultimate judge is the customers because whether the strategy of having brand extension was good or not ultimately the result comes from the consumers.

\section{LITERATURE REVIEW}

\subsection{Brand Extension}

Few of the generally acceptable definitions of the brand extension are as follows: using name of stronger brand of particular product category for entrance in to a new product category 
(Aaker, 1990). Then brand extension is to leverage the strong brand towards a new product category, then further two other heading come under it that is "Ad Hoc Extension" and the other is "Creating Range brand" the basic difference is this that ad hoc is unplanned or we can say the extension took according to the current scenario of market, where as Creating range brand is the preplanned or being came into existence while launching company (Aaker, 1996).

Nowadays in this competitive situation the marketers want to increase their organization portfolio with the diminishing cost of promotion and diluting the risk of the damage to the master brand, so the one of the most popular way is to use the strategy of brand extension (Fox et al., 2001). The strategy of brand extension permits the consumer to form hope about the performance of newly launched product based on the previous knowledge about the existing brand (Keller, 2003). The perceived risk which consumers usually have with respect to the new product will be reduced when the consumer has the knowledge about and familiar with the parent brand (Aaker \& Keller, 1990). In broad, studies of similarity between parent brands and the extended brand that show a directly proportional relation among the category similarity and customer's assessment of the extended brand. When the likeness is high, customer evaluate the extended brand according to the approach of existing brand (Keller \& Aaker, 1997).

\subsection{Parent Brand}

Parent brand can be defined as the name of the actual brand which has been launched with an individually that symbolize the foundation of the brand extension (Apostolopoulou, 2002). As when customer come to shop and first encounter the extension he/she is unfamiliar with that extension, however consumer may have already the knowledge of the parent brand, so he/she might evaluate that extension according to the structure in the mind of parent brand (Bhat \& Reddy, 2001). The parent brand which are dominating in nature are those when their product category is being recalled their name come first in the mind (Herr, Far-Quhar, and Fazio 1996) for example like when some asks about detergent, what comes firstly mind that can be Surf excel or Ariel.

\subsection{Brand Image}

The current perception about the brand is called brand image, although the brand image is tactical in nature unlike brand identity as it is strategic in nature (Aaker, 1996). A positive status or an image of a brand is being considered a worthy competitive advantage for the organization, in studies it has been shown that brand image plays very significant role to evaluate the brand extension by the customers (Kwun \& haemoon, 2007).

\subsection{Brand Identity}

Brand identity is been defined by the Aaker (1996) that "it is the unique combination of associations which represents that what the brand stand for and imply the promise by the employees of the organization to the customers".

The structure of the brand identity is divided in to two parts that is;

- $\quad$ core identity

- $\quad$ extended identity 
whereas core identity mostly not change and remain steady as the brand moves towards the new market or product it is for a long time whereas the extended identity is the element for the brand that completes the brand (Aaker, 1996).

As in the other book of Aaker (2000) says the brand is actually other than a product, according to him extension is important it makes the parent brand stronger and its very important to have the strong extended identity, it will be more clear after viewing this figure.

Figure 2.1(extended and core identity)

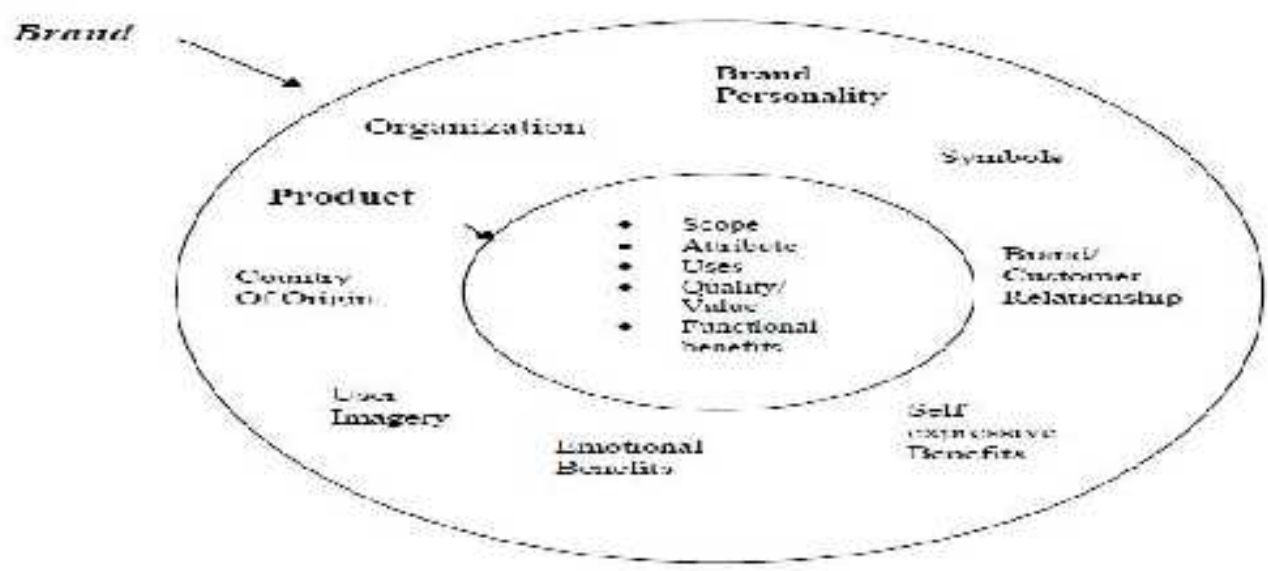

Source: Aaker, 2000

Aaker (2000) says about this picture that extended identity provides the space to move beyond the attributes. As human have usually identity cards by which they can be identified that who they are what they do and the way to reach them, so same is the case with the brand because as the brand have personality same like it has the brand identity as well so the customer can identify the brand (Jean and Kopfere, 2003).

Brand identity will be bit more clear after giving the response of some queries like;

- Vision and objective of brand?

- How it is unique?

- What need the brand is satisfying?

- In which it is consistent?

- What it worth's?

- What are its recognition signals?

After having the answers of the above questions the brand can be easily identified (Jean and Kopfere , 2003).

\subsubsection{Difference between Brand Identity and Brand Image}

As it is for sure and it has been identified in many of the studies that brand identity is from the company side means organizations true self what they want to show to the customers (Aaker, 1996: Jean and Kopfere 2003).

Brand identity is given directly by the organization but the image is been perceived by the customers where that perception is being generated by the noise or competitor these two things are also called extraneous factors which create meaning of the brand bye different ways 
which can be more clear by this diagram .

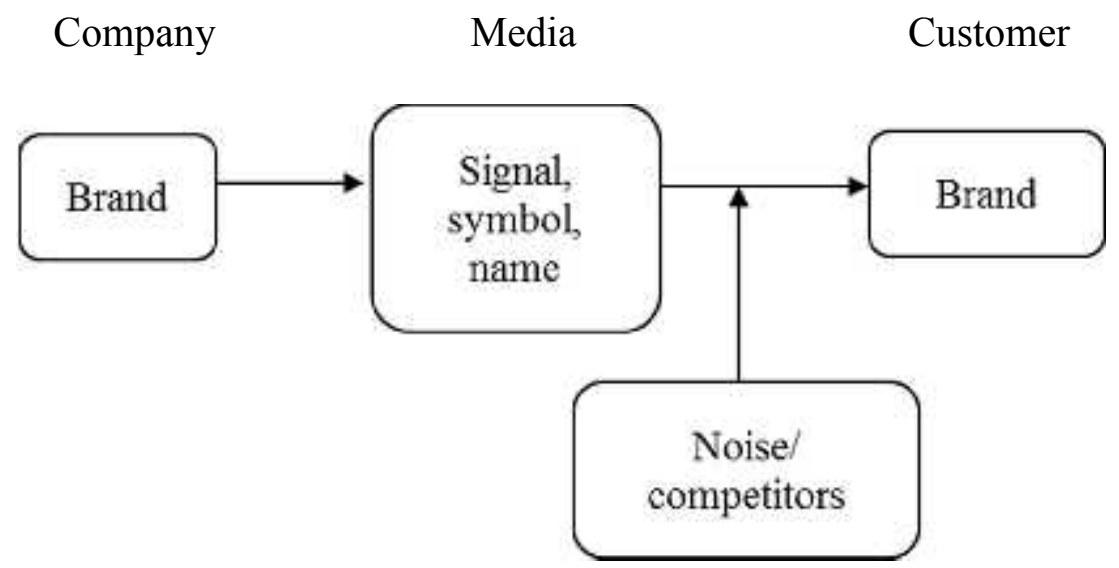

Source: Jean \& Kopferer, 2003

\subsection{Brand Personality}

For any brand most important thing is to make the brand sustainable for the long run by brand equity and to build a brand equity brand personality is one to create it through its three models which are self-expressive model which makes a customer expressive in front of others and second is the relationship model which build a relation of a customer with the brand and the third is the functional benefits model which is also very important for the customers because the first and the foremost thing for the customer is its functional benefits in the brand (Aaker, 1997).

As in the case of person as it has some kind of personality with some unique kind of the dimensions this is the same with the brand personality. There is also a BPS this is also called as big five which is written under in detail.

1. Sincerity

Under which the different variety is available like down to earth means family oriented, for love class and honest and sincere in nature, it show originality, old fashioned, cheerful mean friendly all of these are under the head of sincerity.

2. Excitement

In this kind of personality it shows daring, spirited, imaginative, surprising and artistic comes under this kind of personality

3. Competence

A personality which shows reliability, intelligence and the successfulness.

4. Sophistication

This personality shows the upper class and the charm.

5. Ruggedness

This show outdoorsy means athletic, active and the other is tough. 
By all these personality dimensions every customer tries to select the brand whose personality related to him or her or they might select the brand what they want to be or they might want to make relation with it (Aaker, 1997). Now these are the brand personality dimension by which customers relates him/her with the respective brand personality he/she have or what personality he/she likes will purchase that brand (Hawkins et al, 2001).

Brand personality makes brand more favorable towards the consumers because this gives the meaning to the brand in the customers mind, the concept of the brand personality is new for the marketers and the consumers but it's not new for the advertisers because in early fifties they have started using celebrity endorsement in their advertise after that consumer started matching themselves with those stars and started purchasing those products (Plummer, 1984). Brand personality can be defined as the association of the personality of human with the given brand, thus it includes all the demographics as well like, gender, ager, socioeconomic class etc, for example Tapal Tea is for family whereas Lipton is for the executives by these kind of example one matches himself/herself with the personality or brand to have it (Aaker, 1996).

One person makes friendship or come to a relationship or become a partner because of the personality he or she like or the he or she want to be like that personality same is the case with the brand personality it becomes the partner of the consumer who purchases it and a relation becomes stronger (Aaker, 1997).

\subsection{Brand Knowledge}

In common the brand knowledge can be defined as the structure in the mind containing beliefs and attitudes, which are related with the varied degrees of strength (Broniarczyk and Alba, 1994). In some of the researches it has been shown that the knowledge can be influenced through the belief of the new product with the association of the existing belief (Crocker, Fiske, and Taylor, 1984). Brand knowledge play a vital role other to evaluate the extension by the consumer, the study was done on the respondent were brand experts and the general public or new to brand, two brands has been taken Apple and Compaq with their respective extensions (Broniarczyk \& Alba, 1994).

\subsection{Fit/similarity}

Fit or one can say it similarity plays very significantly in the evaluation of the brand extension in common similarity is referred to that the extended product is being same to the existing product (Aaker and Keller, 1990).

The greater the fit between the existing product that is parent brand and the brand extension the greater the transfer of the attitude that can be negative or positive to the extended brand (Aaker and Keller, 1990).

\subsection{Brand Loyalty}

Brand loyalty is one of the major components of brand equity. All the remaining components of brand equity like brand awareness, brand association and perceived quality may directly or indirectly enhance the brand loyalty, enhance of brand loyalty is very important as after generating the strong brand loyalty there are two things which helps the organization first one is the decrease in the cost of the marketing and the second one is the revenue generating because consumer will heavily pay for that brand for which he/she is loyal (Moisescu, 2011). 


\section{RESEARCH METHODOLOGY \& DATA ANALYSIS}

An instrument was developed to test the relationship among the selected variables. After finalizing instrument a survey was conducted to investigate the key influencing factors. $\mathrm{T}$ To achieve the objective of this study a sample of 100 respondents from big retail super store was selected. Completed questionnaires were collected from the respondents' and data was entered in computer software. Finally the SPSS 15.0 was used for the estimation and analysis of the results.

\section{Descriptive statistics}

Table: 1

\begin{tabular}{|l|c|c|}
\hline & Mean & $\begin{array}{c}\text { Std. } \\
\text { Deviation }\end{array}$ \\
\hline L.Dependent & 3.02 & .82 \\
L.Awaremess & 3.54 & .89 \\
L.Image & 2.94 & 1.13 \\
L.Loyalty & 2.89 & .98 \\
L.Quality & 3.20 & 1.04 \\
L.Personality & 2.96 & 1.08 \\
\hline
\end{tabular}

Table-1 indicates the dependent variable is the evaluation of the brand extension which is Lifebuoy shampoo where as independent variables are Lifebuoy soap awareness, Lifebuoy soap image, Lifebuoy soap loyalty, Lifebuoy soap quality and Lifebuoy soap personality whereas the Lifebuoy soap is the parent brand with the $\mathrm{N}=150$.

Table: 2

\begin{tabular}{|l|c|c|}
\hline & Mean & $\begin{array}{c}\text { Std. } \\
\text { Deviation }\end{array}$ \\
\hline P.Dependent & 3.19 & .77 \\
P.Awareness & 3.18 & .85 \\
P.Image & 3.11 & 1.07 \\
P.Loyality & 2.99 & .92 \\
P.Quality & 3.41 & .95 \\
P.Personality & 3.17 & .99 \\
\hline
\end{tabular}

\section{Source: Survey data 2013}

Table-2 gives the mean and standard deviation of the second brand of this research that is Pakola, here the dependent variable is the brand extension evaluation which is Pakola flavored milk and independent variables of parent brand that is Pakola drink are Pakola drink awareness, Pakola drink image, Pakola drink loyalty, Pakola drink quality and Pakola drink personality with the $\mathrm{N}=150$ 
Table: 3

\begin{tabular}{|l|c|c|}
\hline & Mean & $\begin{array}{c}\text { Std. } \\
\text { Deviation }\end{array}$ \\
\hline K.Dependent & 3.21 & .96 \\
K.Awareness & 3.32 & 1.02 \\
K.Image & 3.12 & 1.27 \\
K.Loyality & 3.10 & 1.13 \\
K.Quality & 3.57 & 1.09 \\
K.Personality & 3.33 & 1.08 \\
\hline
\end{tabular}

\section{Source: Survey data 2013}

Table-3 shows the mean and standard deviation of the last brand of this research that is Knorr, in this research for the brand the dependent variable is the brand extension evaluation which is Knorr ready to cook, where as independent variables are Knorr cubes awareness, Knorr cubes image, Knorr cubes loyalty, Knorr cubes quality and Knorr cubes personality whereas the Knorr cubes is the parent brand, with the $\mathrm{N}=150$.

Table: 4, Correlation Brand "Lifebouy"

\begin{tabular}{|l|l|l|l|l|l|l|}
\hline & L.dependent & L.Awareness & L.image & L.Loyality & L.Quality & L.personality \\
\hline L.dependent & 1.00 & & & & & \\
L.Awareness & .44 & 1.00 & & & & \\
L.Image & .51 & .30 & 1.00 & & & \\
L.Loyalty & .62 & .34 & .64 & 1.00 & & \\
L.Quality & .61 & .42 & .45 & .65 & 1.00 & \\
L.Personality & .51 & .38 & .63 & .82 & .67 & 1.00 \\
\hline
\end{tabular}

Source: Survey data 2013

Table-4 indicates here about correlation whereas L stands for lifebuoy and the dependent variable over here is the evaluation of the brand extension on the basis of the independent variables of the parent brand that is Lifebuoy soap where as its brand extension is Lifebuoy shampoo. The above table shows the association between dependent variable and independent variables. In which it shows that the coefficient of correlation Lifebuoy soap awareness and Lifebuoy shampoo evaluation is 0.438 and the $\mathrm{P}$-value is 0.000 which means that there is the positive strong correlation between the parent brand awareness and its extension evaluation, as far as coefficient of correlation between parent brand image of Lifebuoy soap and the evaluation of its extension that is Lifebuoy shampoo is 0.509 which also shows the strong correlation, similarly the Lifebuoy soap awareness and its shampoo evaluation gives the value of 0.618 which also gives the same result that it has the strong correlation between each other, whereas coefficient of correlation between quality and personality of parent brand with evaluation of its extension is 0.506 which also give the strong correlation between them. 
Table: 5 Brand, Correlation "Pakola"

\begin{tabular}{|l|l|l|l|l|l|l|}
\hline & P.dependent & P.Awareness & P.image & P.Loyality & P.Quality & P.personality \\
\hline P.dependent & 1.00 & & & & & \\
P.Awareness & .45 & 1.00 & & & & \\
P.Image & .55 & .54 & 1.00 & & & \\
P.Loyalty & .61 & .59 & .59 & 1.00 & & \\
P.Quality & .59 & .48 & .47 & .66 & 1.00 & \\
P.Personality & .62 & .50 & .55 & .76 & .64 & 1.00 \\
\hline
\end{tabular}

Source: Survey data 2013

Table-5 here indicates that "P" stands for the brand Pakola, where its dependent variable is the evaluation of its extension this Pakola flavored milk on the basis of independent variables i.e. awareness, image, loyalty, quality and personality of parent brand that is Pakola drink. In this table coefficient of correlation Pakola drink awareness and its extension evaluation is 0.454 which shows the strong correlation between each other, whereas for the Pakola drink image and its extension evaluation also shows the strong correlation with the value of 0.552 , similarly for loyalty, quality and personality of the Pakola drink has a strong correlation with its evaluation of its extension that is Pakola flavored milk with the value of $0.608,0.585$ and 0.624 respectively. That means it shows that all the independent variables of the parent brand that is Pakola drink has the strong correlation with the evaluation of the extension of the Pakola that is Pakola flavored milk.3

Table: 6, Correlation Brand "Knorr"

\begin{tabular}{|l|l|l|l|l|l|l|}
\hline & K.dependent & K.Awareness & K.image & K.Loyality & K.Quality & K.personality \\
\hline K.dependent & 1.000 & & & & & \\
K.Awareness & .54 & 1.00 & & & & \\
K.Image & .60 & .68 & 1.00 & & & \\
K.Loyalty & .68 & .72 & .72 & 1.00 & & \\
K.Quality & .64 & .58 & .59 & .72 & 1.00 & \\
K.Personality & .72 & .60 & .66 & .77 & .76 & 1.00 \\
\hline
\end{tabular}

Source:

Survey data 2013

Table- 6 belongs to the Pearson correlation of the third brand which is Knorr of this research, in this table the K stand for Knorr, where two brands of this company has been taken the first one is parent brand which is Knorr cube and the second is Knorr ready to cook that is brand extension, in this the dependent variable is the evaluation of the brand extension of the Knorr cubes that is Knorr ready to cook and the independent variables which is parent brand variables that is awareness, image, loyalty, quality and personality, where in this table the all these independent variables shows the strong association with the brand extension evaluation that is Knorr ready to cook with the values of $0.55,0.600,0.679,0.635$ and 0.721 respectively.

Table: 7, Multiple Regression "Lifebuoy Brand" 


\begin{tabular}{|l|l|l|l|l|}
\hline Variables & coefficients & t-value & $\mathrm{p}$-value & VIF \\
\hline (Constant) & .69 & 2.61 & .01 & \\
L.Awaremess & .18 & 2.45 & .02 & 1.25 \\
L.Image & .14 & 1.96 & .05 & 1.82 \\
L.Loyalty & .36 & 3.19 & .00 & 3.55 \\
L.Quality & .27 & 3.36 & .00 & 2.04 \\
L.Personality & -.21 & -1.99 & .05 & 3.62 \\
\hline AdjustedR ${ }^{2}=0.494$ & \multicolumn{4}{|c|}{ F-statistics $=20.363$} \\
\multicolumn{2}{|c|}{ p value $=0.000$} \\
\hline
\end{tabular}

This table shows that the lifebuoy whose parent brand is lifebuoy soap which is very old in Pakistani market and its impact on brand extension that is Lifebouy Shampoo, so here this table shows that the Awareness, image, loyalty and quality has positive significant relation that is $0.02,0.05,0.00$ and 0.00 respectively with the consumer evaluation of extension that is lifebuoy shampoo where as image of lifebuoy soap has no relation with the extension evaluation and personality of lifebuoy soap has negative significant relation with the evaluation of brand extension that is Lifebouy Shampoo. Where as Adjusted R2 is explaining 49.9\% of dependent variables with respect to the dependent variable. So $\mathrm{HoA}, \mathrm{HoB}, \mathrm{HoC}, \mathrm{HoD}$ and $\mathrm{HoE}$ are Rejected.

Table: 8, Multiple Regression "Pakola Brand"

\begin{tabular}{|l|l|l|l|l|}
\hline Variables & Coefficient & t-value & p-value & VIF \\
\hline (Constant) & 1.08 & 4.36 & .00 & \\
P.Awareness & .03 & .30 & .77 & 1.71 \\
P.Image & .16 & 2.30 & .02 & 1.74 \\
P.Loyality & .10 & .94 & .36 & 3.12 \\
P.Quality & .18 & 2.24 & .03 & 1.96 \\
P.Personality & .19 & 2.11 & .04 & 2.66 \\
\hline Adjusted $\mathrm{R}^{2}=0.472$ & \multicolumn{4}{|c|}{ F-statistics $=18.670$} \\
& & \multicolumn{4}{|c|}{$\mathrm{p}$ value $=0.000$} \\
\hline
\end{tabular}

Here in this table the value of Adjust $\mathrm{R}^{2}$ is $47.2 \%$ that means it is explaining $47.2 \%$ variance on dependent variable. This table shows that the image, quality and personality of the parent brand that is pakola drink is positively significant related to the evaluation of brand extension that is Pakola flavored milk with the value of $0.24,0.28$ and 0.38 respectively so Hypothesis $\mathrm{HoB}, \mathrm{HoD}$, and $\mathrm{HoE}$ is Rejected where as loyalty and awareness are not significant so HoA and $\mathrm{HoC}$ are accepted in the case of pakola drink and flavored milk. 
Table: 9, Multiple Regression "Knorr Brand"

\begin{tabular}{|l|l|l|l|l|}
\hline Variables & Coefficients & t-value & $\mathrm{p}$-value & $\mathrm{VIF}$ \\
\hline & & & & \\
\hline (Constant) & .82 & 3.25 & .00 & \\
K.Awareness & .03 & .25 & .80 & 2.34 \\
K.Image & .09 & 1.18 & .24 & 2.43 \\
K.Loyality & .15 & 1.36 & .00 & 3.84 \\
K.Quality & .10 & 1.04 & .80 & 2.66 \\
K.Personality & .35 & 3.23 & .24 & 3.28 \\
\hline Adjusted $\mathrm{R}^{2}=0.547$ & \multicolumn{3}{|c|}{ F-statistics $=24.906$} \\
\end{tabular}

Adjusted $\mathrm{R}^{2}$ is explaining $54.7 \%$ of variance in independent variables with respect to the dependent variable here this table is explaining about parent brand which is knorr cubes and the brand extension of parent brand that is Knorr ready to cook so this shows that the only parent brand loyalty is positively significant related to the evaluation of the brand extension that is knorr ready to cook. Therefore $\mathrm{HoC}$ is rejected and with the value of 0.002 and all the four remaining hypothesis is accepted that means there is no significant impact of brand awareness, image, quality and personality in the case of the knorr cubes and ready to cook.

\section{CONCLUSION \& RECOMMENDATION}

This research is conducted on the impact of parent brand on brand extension, the industry which has been taken is FMCG industry in which researcher has selected three realistic brands and their realistic extensions which were lifebuoy, pakola and knorr the extension which has been selected were lifebuoy shampoo, pakola flavored milk and knorr ready to cook respectively, results explains that awareness, loyalty, image and quality are positively significant in the case of lifebuoy brand whereas personality has the negative significant impact for the customer evaluation of brand extension. Secondly in the case of pakola brand image, quality and the personality have the significant relation whereas loyalty and awareness has the no significant relation for the evaluation of the brand extension by customers. Thirdly for the knorr brand the loyalty has the only significant relation with the evaluation of extension and image, quality, awareness and personality has no significant relation with its evaluation of extension.

\section{Recommendation}

For every company in the FMCG industry it is very important that before leveraging their brand through extension strategy they must analyze that where their brand stands in the mind of the customer so they can easily give and satisfy the need of the customers as in every case which has been analyzed in this study shows that somewhat any of the parent brand factor can influence the company's brand extension in the mind of the customer as in the case of knorr they were unique and pioneer in providing the value addition in the food so they utilized that thing and launched their knorr ready to cook which was unique in itself, same was the case in the lifebuoy soap even the personality of the lifebuoy soap was negative but the company 
analyzed that this particular market which lower needs some special attention as well and they launched lifebuoy shampoo which was highly appreciated by the market because it was need of that particular market, and if we analyze the result of pakola flavored milk they launched something very new in the market although the pakola is ice cream soda and its extension is flavored milk which was highly appreciated, so it is very important for the marketing manager or higher management of the company that before launching their brand extension they must know that which factor of the parent brand can influence the evaluation of the extension by the customers. That can be the quality, image, loyalty, awareness or personality of the parent brand.

\section{REFERENCES}

Aaker and Keller. 1990. Consumer Evaluations of Brand Extensions. Journal of Marketing 54 (1), 27.

Aaker, D. A. 1996. Building strong brands, The Free Press. New York: A Division of Simon \& Schuster Inc.

Aaker, D. A. et al. 2000. Brand Leadership. New York: The Free Press.

Aaker, D.A., 1990. Brand Extensions: The Good, the Bad and the Ugly. Sloan Management Review 31 (4), 47-56.

Aaker, J.L. 1997. Dimensions of Brand Personality, Journal of Marketing Research, Vol. 34, Issue 3, p.347.

Ambler, T., and Styles, C., 1997. Brand Development versus New Product Development: Apostolopoulou, A. 2002. Brand Extensions by U.S. Professional Sport Teams: Broniarczyk, Susan M., and Alba, Joseph W.: The Importance of the Brand in Brand Extension. Journal of Marketing Research XXXI (May 1994): 214-228

Cochen Wu, Y.-C. Y. (2007). How the Strength of Parent Brand Associations Influence the Interaction Effects of Brand Breadth and Product Similarity With Brand Extension Evaluations. Journal of Product and Brand Management, 334-341.

D.J. Kwun, H. Oh. Consumers' Evaluation of Brand Portfolios, Journal of Hospitality Management 26 (2007) 81-97

David Joon-Wuk Kwun, H. O. (2007). Consumers' Evaluation of Brand Portfolios, Journal Hospitality Management, 81-97.

Dr Leif E. Hem, L. d. (2001). Factors Influencing Successful Brand Extensions.

Eva Martínez Salinas, J. M. (2009). Modeling the brand extensions' Influence on Brand Image. Journal of Business Research, 50-60.

Eva Martinez, Y. P. (2007). Effect of Brand Extension Strategies on Brand Image A Comparative Study of the UK and Spanish Markets. International Marketing Review, 107-137.

Fox, R.J., Reddy, S.K., Swaminathan, V. 2001. The Impact of Brand Extension

Hawkins, D., Best, R. \& Coney, K. 2001. Consumer Behavior: Building Marketing Strategy. New York Irwin: McGraw-Hill.

Hongwei He, Y. L. (2010). Consumer Evaluation of Technology-Based Vertical Brand Extension. European Journal of Marketing, 1366-1383.

Jalees, T. (2009). Relationship between Brand Personification of Parent Brand and Brand Extension. Market Forces, 154-165

Keller, K.L., Sood, S. 2003. Brand Equity Dilution, MIT Sloan Management Review, Vol. 45, Issue 1.

Ko de Ruyter, M. W. (2000). The Role of Corporate Image and Extension Similarity in Service Brand Extensions. Journal of Economic Psychology, 639-659.

Kuang-Jung Chen, C.-M. L. (2004). Positive Brand Extension Trial and Choice of Parent Brand Journal of Product and Brand Management, 25-36. 
Mary R. Zimmer, S. B. (2004). The Reciprocal Effects of Extension Quality and Fit on Parent Brand Attitude. Journal of Product \& Brand Management, 37-46.

N. Thamaraiselvan, J. (2008). How do Consumers Evaluate Brand Extensions Research Findings from India. Journal of Service Research.

Plummer, J.T. (1984) How Personality Makes a Difference. Journal of Advertising Research, 24, 27-31.

S. Bhat, S.K. Reddy / Journal of Business Research 53 (2001) 111-122

Sheinin, D. A. (2000). The Effects of Experience with Brand Extensions on Parent Brand Knowledge. Journal of Business Research, 47-55.

Sobodh Bhat, S. K. (2001). The Impact of Parent Brand Attributes Associations and Effect on Brand Extension Evaluation. Journal of Business Research, 111-122.

Thamer Baazeem, L. N. (2009). The Effect of Brand Extensions on Parent-Brand Relationship Quality. anzmac.

The Importance of the Brand in Brand Extension Author(s): Susan M. Broniarczyk and Joseph W. Alba Source: Journal of Marketing Research, Vol. 31, No. 2, Special Issue on Brand Management (May, 1994), pp. 214-228Published 